\title{
Blueberries and cardiovascular disease prevention
}

Eleanor Wood ${ }^{1}$, Sabine Hein ${ }^{1,2}$, Christian Heiss ${ }^{3,4}$, Claire Williams ${ }^{2}$, Ana Rodriguez-Mateos ${ }^{1 *}$

${ }^{1}$ Department of Nutritional Sciences, School of Life Course Sciences, Faculty of Life Sciences and Medicine, King's College London, UK ${ }^{2}$ School of Psychology \& Clinical Language Sciences, University of Reading, UK; ${ }^{3}$ University of Surrey, Faculty of Health and Medical Sciences, Guildford, UK ; ${ }^{4}$ Surrey and Sussex Healthcare NHS Trust, Redhill, UK

\section{Correspondence*:}

Ana Rodriguez-Mateos; ana.rodriguez-mateos@kcl.ac.uk; +44(0) 207848 4349; Department of Nutritional Sciences, School of Life Course Sciences, King's College London, Franklin-Wilkins Building, 150 Stamford Street, London, SE1 9NH 


\begin{abstract}
Blueberries are a rich source of (poly)phenols, particularly anthocyanins. Epidemiological studies indicate that anthocyanin-rich foods including blueberries are associated with a reduction in the risk of cardiovascular disease. These observational findings are supported by a number of randomized-controlled trials showing improvements in biomarkers of cardiovascular disease risk. The beneficial effects of blueberry (poly)phenols is particularly clear when measuring flowmediated dilation over various timeframes and study populations. However, other outcomes are less clear, such as effects on blood pressure, arterial stiffness and blood lipid profile. This may be due to the heterogeneity existing in study designs, such as duration of the intervention, and the health status of participants. Longer-term RCTs using gold standard methods in relevant populations which can be translated to the general public are needed to clarify and strengthen the evidence available. While circulating phenolic blueberry metabolites have been linked with improvements in vascular function, the biological activities and mechanisms of action of individual metabolites and their interaction in vivo are still unknown. Evaluating the bioactivities of metabolites alone and together, analyzing their structure-activity relationship in well-designed and physiologically relevant experimental and human studies are needed to understand the mechanisms of how these metabolites affect vascular function.
\end{abstract}




\section{Introduction}

The health benefits of blueberries are of particular interest of late due to their high content of phytochemicals known as (poly)phenols (Table 1) (1). Several epidemiological studies suggest that the high (poly)phenol content of blueberries, particularly a subclass known as anthocyanins, may be responsible for their cardiovascular health benefits (2-4). Recent meta-analyses and systematic reviews of randomised-control trials (RCTs) support that anthocyanin-rich foods such as berries can improve endothelial function and arterial stiffness $(3,5,6)$, lower fasting and postprandial glucose, total cholesterol, and $\operatorname{LDL}$-cholesterol $(4,7,8)$, and may reduce the risk of developing cardiovascular diseases (CVD) via these routes. The aim of the current review is to discuss the current evidence from epidemiological studies and RCTs on the effects of blueberries on CVD risk.

\section{(Poly)phenol content of blueberries}

Blueberries are a rich source of (poly)phenols including anthocyanins, procyanidins, flavonols, and phenolic acids (Fig. 1) (9, 10). They are particularly high in anthocyanins, which are red, blue, or purple pigments that play a key role in plant pollination as well as protection from ultra-violet induced damage by absorbing light $(5,11)$. At least 27 structurally different anthocyanins have been identified in blueberries, including glucosides, galactosides, and arabinosides of five anthocyanidins: delphinidin, malvidin, petunidin, cyanidin and peonidin (12). The anthocyanin content of blueberries is very variable, typically ranging from 114-487 mg/100 g fresh weight (FW) of fresh fruit (13-15). Total flavan-3-ol content range from 33-333 mg/100 g FW of which most are oligomeric and polymeric forms of B-type proanthocyanidins, which have low bioavailability $(14,16)$. Unlike cocoa, very little flavan-3-ol monomers are present in blueberry $((+)$-catechin and (-)-epicatechin). Flavonols range from 11-39 mg/100 g FW, and the most abundant phenolic acids are the chlorogenic acids, ranging from 43-114 mg/100 g FW (Figure 1) $(10,14)$. There are many factors which will affect the (poly)phenol content of blueberries such as the type of blueberry species, fruit ripeness, size, growing climate, environment, and storage after harvest (17-19). Cooking, baking, and processing overall can also cause significant changes in the (poly)phenol content of blueberries post-harvest, in particular anthocyanin content can 
decrease dramatically during storage, juice processing, or when subjected to baking (20). Therefore, due to large diversity in (poly)phenol content both within and between blueberry species, and due to changes during storage and processing, it is important to measure the (poly)phenol content of each batch of blueberry used, particularly when assessing health benefits in preclinical and clinical studies. Reliable analytical methods for the analysis of (poly)phenols in blueberries should be used, such as liquid/gas chromatography coupled with UV-Visible, electrochemical detection or mass spectrometry, as non specific methods such as the FolinCiocalteu or the $\mathrm{pH}$ differential method can lead to important sources of errors (21). The use of authentic standards for quantification is recommended for accurate results (22).

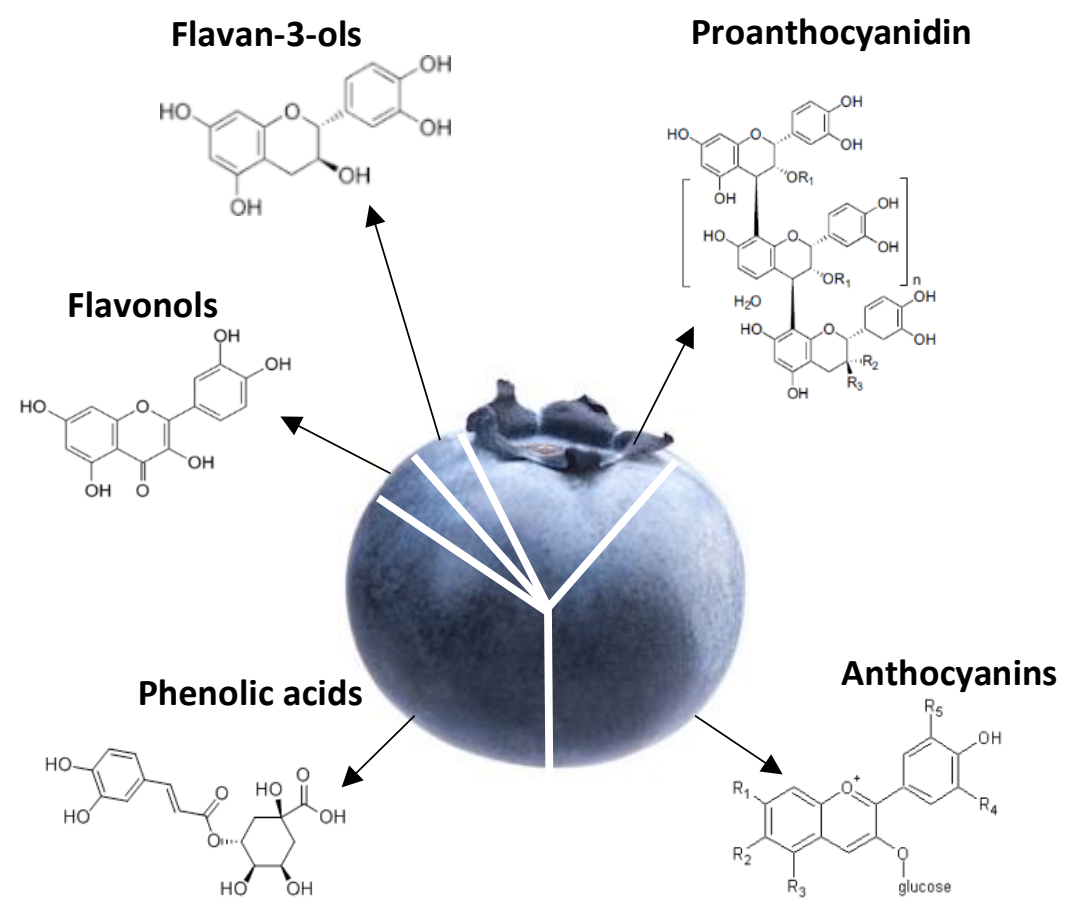

Figure 1. Main (poly)phenol groups found in blueberries

\section{Absorption, distribution, metabolism, and excretion (ADME) of blueberry (poly)phenols}

In blueberries, the ADME of anthocyanins is of particular interest as they likely mediate their vascular effects via their circulating metabolites (23). It is known that anthocyanins themselves have a low bioavailability, with less than $1 \%$ of the parent compounds being recovered in urine (24-26). However, novel insights in the last decade have demonstrated that the metabolism of anthocyanins is more complex than previously thought and a large number of phenolic 
metabolites resulting from the chemical and microbial degradation of anthocyanins in the gastrointestinal tract reach circulation in up to micromolar concentrations. Vitaglione and colleagues (2007) demonstrated extensive degradation of cyanidin-3-O-glucoside (C3G) to protocatechuic acid in the small intestine within $2 \mathrm{~h}$ of blood orange juice consumption (27). More recently, a stable isotope-labelled human study in 8 males investigated the concentration of anthocyanins in plasma, urine and faecal samples over $48 \mathrm{~h}$ post-consumption of $500 \mathrm{mg}{ }^{13} \mathrm{C}$ isotopically labelled C3G (28). The total recovery of the ${ }^{13} \mathrm{C}$ dose was $44 \%$, with $5.4 \%$ recovered in urine, $6.9 \%$ in breath and $32 \%$ in feces. The authors reported a total of $35{ }^{13} \mathrm{C}$-labelled metabolites, including the parent C3G, identified in the samples overall. The analysis showed that the majority of the ${ }^{13} \mathrm{C}$ label were present in the circulation as low molecular weight phenolic metabolites of the parent C3G, such as protocatechuic, vanillic, caffeic, ferulic and phenylacetic acid derivatives (29). Besides chemical degradation in the gastrointestinal tract, anthocyanins undergo various processes such as phase I and phase II metabolism, microbial metabolism and enterohepatic recirculation, leading to a large number of metabolites being formed at various timepoints over a $48 \mathrm{~h}$ period (29). Enzymes produced by the bacteria in the intestine can hydrolyse glycosides, sulfates and glucuronides, as well as perform complex reactions such as oxidation, demethylation, reduction, decarboxylation and ring fissions to produce smaller catabolites (30). Therefore, when studying the health effects of anthocyanin-rich food sources, it is important to consider the wide range of metabolites produced as well as their kinetics.

Recent studies using authentic standards and validated methods for analysis have investigated the fate of anthocyanins and other (poly)phenols after blueberry consumption (31). In healthy men, 19 metabolites increased in plasma $2 \mathrm{~h}$ after the consumption of wild blueberry. Those metabolites included benzoic acid, catechol, flavonol, hippuric, and cinnamic acid derivatives, with catechol-O-sulfate, benzoic and vanillic acid representing the major changes after $2 \mathrm{~h}$ consumption, demonstrating again that anthocyanins are largely transformed into smaller phenolic compounds already in the upper GI tract (Fig. 3A). After daily wild blueberry consumption for one month, hippuric acid was the compound with the highest increase in plasma of volunteers, followed by catechol-O-sulfate and 3-hydroxyhippuric acid (Fig. 3B). In this study, the metabolites measured in circulation illustrate that blueberry (poly)phenols are absorbed and 
extensively metabolised by phase II enzymes and by the gut microbiota. This results in a variety of circulating metabolites that may be responsible for their observed health benefits following blueberry consumption rather than the less bioavailable parent anthocyanins present in blueberries.

There are several important factors that may affect the bioavailability of blueberry (poly)phenols. For example, the absorption of various phenolic metabolites could be increased, unaltered, or decreased when consumed together with other foods rich in proteins, carbohydrates (i.e., fibres), or fats (17). As well as the food matrix, food processing has also been reported to affect the bioavailability of blueberry (poly)phenols (20). Another factor to consider is inter-individual differences in (poly)phenol ADME. In the same study previously mentioned (31), interindividual-variability, expressed as coefficient of variation (CV\%), ranged between 40$48 \%$ in plasma and $47-54 \%$ in urine. Which factors may be responsible for such variability is currently unknown, although some evidence suggest host genetic and epigenetic variations in metabolizing enzymes, differences in gut microbiota composition, sex, age, and dietary habits may play an important role in inter-personal differences (32).

a

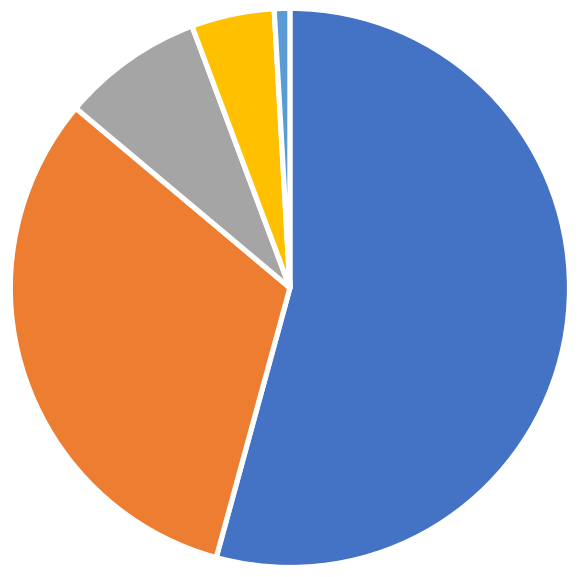

- $54.3 \%$ Catechols

-31.9\% Benzoic acids

$8.2 \%$ Cinnamic acids - $0.9 \%$ Flavonols

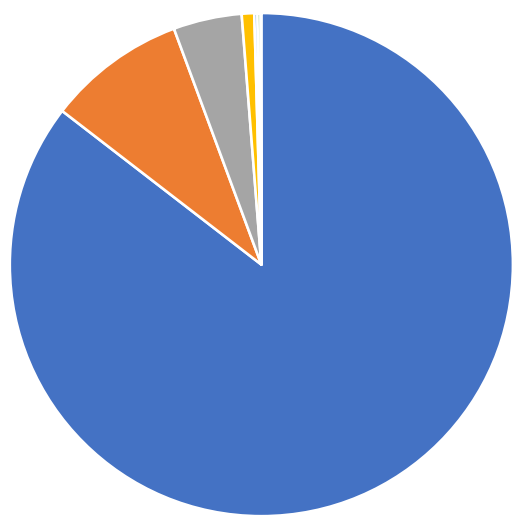

- $85.5 \%$ Hippuric acids

- $4.4 \%$ Benzoic acids

$0.2 \%$ Phenylacetic acids

- $0.05 \%$ Flavonols 
Figure 3. Percentage of (poly)phenols main subclasses found in plasma a) $2 \mathrm{~h}$ and b) 1 month postblueberry consumption in healthy men (31).

\section{Epidemiological evidence on anthocyanin and blueberry (poly)phenol consumption and cardiovascular disease risk}

Epidemiological evidence provides associations between high intakes of berries and other anthocyanin-rich foods and low incidence of CVD mortality and morbidity (33-36). A metaanalysis of 14 prospective cohort studies, varying between 6 to 28 year follow-ups, reported an association between higher anthocyanin intake and a 11\% reduction of future CVD risk, CVD defined as coronary heart disease (CHD), stroke, cardiac arrest, heart failure and sudden death (37). Supporting these findings, a more recent meta-analysis of 22 prospective studies, also found an $11 \%$ reduction in both all-cause mortality and CVD risk in those with high anthocyanin intakes compared with low intakes (38). Findings from the Nurse's Health Study (NHS), analysing the dietary patterns of 93,600 healthy women, aged 25-45 years, showed a significant relationship between intake of $>3$ portions of strawberries and blueberries per week and a lowered risk of myocardial infarction by $34 \%$ over an 18 -year follow up (39). Findings from the Kuopio Ischemic Heart Disease Risk Factor Study (KIHD) in 1,950 males, with no history of CVD at baseline, showed that men with the highest berry intake (>408 g/day) compared with the lowest intake $(<133$ g/day) had a significantly lower risk of CVD mortality, defined as CHD, stroke, cardiac arrest, heart failure and sudden death (40), during a 13-year follow up (35). Data from the lowa Women's Health prospective study, following almost 35,000 post-menopausal women, free of CVD at baseline, for 16 years, found higher anthocyanin intakes were associated with a reduced risk of CHD, total CVD (CHD, stroke, cardiac arrest, heart failure and sudden death) (40), and total mortality by $12 \%, 9 \%$, and $10 \%$, respectively (36).

Although promising evidence, there are important limitations in the epidemiological studies conducted so far. The estimation of food consumption or (poly)phenol intake is based on self-reported Food Frequency Questionnaires (FFQ), which are known to have a high degree of bias and inaccuracy (41). In addition, food composition databases for (poly)phenols such as the 
Phenol explorer (14) and the USDA database (42), are still limited to some foods and lack accuracy. As mentioned before, levels of anthocyanins, as well as other flavonoids, in blueberries and other foods will vary depending on the storage, cooking methods and conditions that the food was grown in. One way of overcoming these limitations in the future is the development of validated biomarkers of blueberry/anthocyanin intake, a promising approach in nutritional epidemiology, which is still in its infancy (43).

\section{Clinical dietary intervention studies on the cardiovascular health benefits of blueberries and anthocyanins}

As epidemiological studies investigate the association of habitual dietary intakes with hard outcomes of CVD, they do not provide enough evidence to infer cause-and-effect relationships as several other factors may influence the incidence and progression of CVD. Therefore, the most reliable method to better understand whether blueberry (poly)phenols are cardioprotective is to conduct well-designed RCTs using surrogate markers of CVD risk. There have been several small, short-term human intervention studies investigating the effects of blueberries on validated surrogate markers of CVD risk, namely blood pressure, endothelial function, arterial stiffness, lipids, glucose, and platelet activation. In this section, we will discuss the most relevant human RCTs investigating the effect of blueberries and anthocyanins on at least one of these biomarkers.

Effects on endothelial function. An established marker for the initiation and progression of CVD is endothelial function (44). A validated measure for endothelial function in humans is flow-mediated dilation (FMD) in the brachial artery using high-resolution ultrasound (45). Another commonly used marker of endothelial function is endothelial peripheral artery tonometry (endo-PAT), which measures reactive hyperaemia index (RHI) of the fingertips. Previous meta-analyses have demonstrated that a $1 \%$ increase in FMD of the brachial artery translates to a $10-13 \%$ decreased risk of CVD (46-48). Several studies have investigated the effects of blueberries on endothelial function $(23,49-57)$. Six of the RCTs used FMD of the brachial artery to assess endothelial function whilst the remaining 7 used endo-PAT.

The RCTs investigating the effect of blueberry on FMD included time- and dosedependent study designs and reported significant improvements in FMD, in 2 separate groups of young healthy males, at 1,2 , and $6 \mathrm{~h}$ post-consumption of a whole freeze-dried wild blueberry 
drink containing $319,639,766,1,278$, or $1,791 \mathrm{mg}$ total (poly)phenols $(129,258,310$, 517, or 724 mg anthocyanins) equivalent to $100-560 \mathrm{~g}$ of fresh wild blueberries (52). Significant intakedependent increases in FMD between 1.2 and $2.4 \%$ were observed, even at the lowest amount tested (100 g) which is still a relatively large amount only consumed in the highest quartiles of some of the epidemiological studies discussed above. The maximum effect was shown at the equivalent to $240 \mathrm{~g}$ of fresh wild blueberries and further amounts did not further increase FMD. Another study, in 10 young healthy males, supported these findings by showing a timedependant improvement in FMD 1, 2 and $6 \mathrm{~h}$ post-consumption of baked blueberry products, and a blueberry drink, both containing $34 \mathrm{~g}$ freeze-dried blueberry powder, the baked products contained $196 \mathrm{mg}$ anthocyanins and the drink contained $339 \mathrm{mg}$ (56). A recent study investigated the effects of daily wild blueberry consumption for 4-weeks on FMD in 40 young healthy males (23). FMD increased in the wild blueberry group by $1.5 \% 2 \mathrm{~h}$ post-consumption and by $2.3 \%$ after 4-weeks daily consumption of $22 \mathrm{~g}$ freeze-dried blueberry (300 mg anthocyanins, equivalent to $200 \mathrm{~g}$ of fresh blueberries). This suggests that daily consumption of blueberry (poly)phenols can improve FMD in healthy individuals. Supporting these findings in a high CVD risk population, a recent RCT in 115 participants with metabolic syndrome reported a $1.4 \%$ increase in FMD following consumption of $26 \mathrm{~g}$ freeze-dried blueberries (364 mg anthocyanins, equiv to $150 \mathrm{~g}$ of fresh blueberries) for 6 months (53). No effect in the group receiving a lower blueberry amount (13 g freeze-dried, $75 \mathrm{~g}$ fresh blueberries; $182 \mathrm{mg}$ anthocyanins) was found, suggesting intake dependent effects of long-term blueberry intake on FMD (53). Therefore, longer-term consumption of large amounts of blueberries can improve FMD significantly in both healthy individuals and those at higher risk of CVD, which could result in a reduction of future CVD risk.

Of the studies using endo-PAT, rather than FMD, as a measure of endothelial function, 3 out of 6 found significant improvements following a blueberry treatment compared with a control. A significant improvement in $\mathrm{RHI}$ after consumption of $22.5 \mathrm{~g}$ freeze dried blueberry powder (290 mg TP, 1 cup fresh weight blueberries) for 6-weeks was found in men and women with metabolic syndrome (54). Another RCT found that $300 \mathrm{~g}$ blueberries (309 mg TP) counteracted the reduction in $\mathrm{RHI}$ after smoking a cigarette compared with the control group using young healthy smokers (55). A similar study in young smokers and non-smokers with low 
RHI scores $(<1.67)$, found that $300 \mathrm{~g}$ of blueberries (309 mg TP) increased RHI 2 h postconsumption in both groups compared with the controls (51). However, one study investigating $25 \mathrm{~g}$ freeze-dried blueberry powder (375 mg anthocyanins) in 18 males, found no effect on RHI 6-weeks post-consumption (57). Participants in this study had one or more CVD risk factors, such as pre-hypertension (systolic blood pressure and diastolic blood pressure of 120-139 and 80-89 $\mathrm{mmHg}$ respectively), high total cholesterol ( $\geq 5.17 \mathrm{mmol} / \mathrm{L})$, low HDL-cholesterol $(\leq 1.09 \mathrm{mmol} / \mathrm{L})$, high LDL-cholesterol ( $\geq 3.36 \mathrm{mmol} / \mathrm{L})$, overweight $\left(B M I 25-30 \mathrm{~kg} / \mathrm{m}^{2}\right)$ and smoking $(<10$ cigarettes/day) (57). The authors concluded that the lack of results may be due to inter-individual differences in both CVD risk factors and ADME of blueberry (poly)phenols. Another study showing no effect on $\mathrm{RHI}$ was conducted in 19 women, with at least 2 risk factors for developing type-2 diabetes (49). Participants consumed a blueberry juice, containing $314 \mathrm{mg}$ anthocyanins, or a placebo, for one-week in a cross-over RCT with an 8-day wash-out period. In addition, a study investigating the effects of blueberries on endothelial function, in 10 healthy male subjects, found no effect on RHI at 1, 2 and $24 \mathrm{~h}$ following $300 \mathrm{~g}$ (fresh weight) of blueberry consumption (50). The lack of findings in this study may be due to the short duration of the intervention, as well as a short wash-out period of 8-days. In summary, 9 RCTs have reported acute and chronic improvements in endothelial function following consumption of 100 to $560 \mathrm{~g}$ of blueberries in young healthy individuals as well as individuals with metabolic syndrome and smokers. In contrast, 3 studies, conducted with endo-PAT, did not find any significant differences.

Effects on blood pressure. Arterial hypertension is one of the most important independent risk factors of $\operatorname{CVD}(58,59)$. A recent meta-analysis of 123 studies, with 613,815 participants, concluded that a $10 \mathrm{mmHg}$ reduction in systolic blood pressure (SBP) reduced the risk of major CVD events by $20 \%$ (60). However, the ability of blueberry (poly)phenols to improve blood pressure is less clear as compared to FMD. A meta-analysis of 6 RCTs, investigating the effects of blueberries on blood pressure, with durations ranging from 6-8 weeks, found no significant changes in SBP or diastolic blood pressure (DBP) (2). Johnson et al. (2015) conducted a well-controlled RCT investigating the effects of $22 \mathrm{~g}$ freeze-dried blueberry powder (469 mg TP) after 8-weeks daily consumption in pre- and stage-1 hypertensive, postmenopausal women (61). The authors reported a significant reduction in SPB and DBP by $7 \mathrm{mmHg}$ and $5 \mathrm{mmHg}$ 
,respectively. A more recent RCT investigating daily blueberry consumption ( $20 \mathrm{~g}$ of freeze dried, $200 \mathrm{~g}$ fresh) for 4-weeks on ambulatory ( $24 \mathrm{~h}$ ) blood pressure in healthy males, found a significant reduction in SBP of $5.6 \mathrm{mmHg}$, but no significant reduction in DBP (23). In a single blinded RCT, 8-weeks daily consumption of a freeze-dried blueberry drink (742 mg TP) compared with a control (water), led to a decrease in SBP and DBP of $7.8 \mathrm{mmHg}$ and $2.5 \mathrm{mmHg}$ in men and women with metabolic syndrome (62).

One study found no significant changes in blood pressure in healthy young smokers following daily consumption of $250 \mathrm{~g}$ fresh blueberries for 3-weeks, compared to a control group who had no intervention (63). Participants were also asked to follow a specific diet which prohibited large amounts of fruit and vegetables. The lack of significant findings may have been due to a short timeframe of the intervention, or possibly due to decreasing the participant's habitual (poly)phenol intake during the study, which may have masked any additional benefits of the blueberry treatment (63).

Many of the studies investigating the effects of blueberries on blood pressure are over short durations, ranging from acute studies to long-term studies lasting 1-8 weeks (Table 2). Furthermore, only one study investigating the effects of blueberries on blood pressure uses $24 \mathrm{~h}$ ambulatory blood pressure, which is considered the gold standard measurement. In summary, more longer-term RCTs using $24 \mathrm{~h}$ ambulatory blood pressure measurements are required, to confirm whether blueberry (poly)phenols can improve blood pressure following daily intake.

Effects on arterial stiffness. Arterial stiffness is a validated marker for future CVD risk. Techniques used to measure arterial stiffness include pulse wave velocity (PWV), particularly the carotid-femoral PWV, and augmentation index (Alx). Very few studies have investigated the effect of blueberry consumption on arterial stiffness. A parallel, 8-week blueberry intervention trial in pre- and stage-1 hypertensives, found that following daily blueberry consumption (469 mg TP), brachial-ankle PWV reduced when compared with the control but carotid-femoral PWV did not change (54). Another study, in participants with metabolic syndrome, showed an improvement Aix (-2.24\%) following daily consumption of blueberries (26 g freeze-dried blueberries) for 6-months (53). However, more recent results showed no improvements in arterial stiffness following both acute and 4-week daily consumption of $22 \mathrm{~g}$ freeze-dried 
blueberries (150 mg anthocyanins) in 40 healthy individuals (23). This could be due to a relatively short intervention period, and changes in arterial stiffness may take longer than 4-weeks to become apparent.

Effects on blood lipids. High plasma cholesterol, or hypercholesterolemia, is another wellestablished marker for future CVD risk. A previous meta-analysis of 16 RCTs assessed the effects of Vaccinium berries on blood lipids, of which 3 were on blueberries (64). The authors found no significant effect on blood lipids when combining the blueberry RCTs. More recently, a RCT in 113 healthy men and women with mild-cognitive impairments $(\mathrm{MCl})$ investigated the effects of consuming $35 \mathrm{~g}$ freeze-dried blueberry powder daily for 6-months compared to a control (65). No differences were found between treatment groups in plasma triglycerides, LDL-cholesterol, HDL-cholesterol, and total cholesterol levels at 3 or 6 months. A crossover RCT in healthy men and women investigated the effects of $150 \mathrm{~g}$ blueberries for 4-weeks combined with exercise, or a control with only exercise (66). The authors reported a $0.13 \mathrm{mmol} / \mathrm{L}$ increase in $\mathrm{HDL}$-cholesterol in the blueberry group. A recent RCT conducted over 6-months in 115 participants with metabolic syndrome, showed an improvement in HDL-cholesterol following daily consumption of $26 \mathrm{~g}$ freeze-dried blueberry powder compared to placebo (53). However, this was only seen in nonstatin users (excluding $\mathrm{n}=44$ ) and was a reasonably small increase of $+0.05 \mathrm{mmol} / \mathrm{L}$. Overall, there is no firm evidence suggesting blueberry consumption can have an effect on the lipid profile, except for 2 RCTs reporting an improvement in HDL-cholesterol.

Effects on blood glucose and insulin sensitivity. Plasma glucose levels and insulin sensitivity are important parameters in identifying pre-diabetes or diabetes. Uncontrolled plasma glucose levels are a major risk factor for future CVD. A small number of studies have investigated the effects of berries on blood glucose and insulin sensitivity with many of these studies finding no effects, this seems to largely depend on the methods used to measure these outcomes (1). A study in individuals with obesity and insulin resistance (but no diabetes), found a $22 \%$ improvement in insulin sensitivity, measured using a hyperinsulinemic-euglycemic clamp which is the gold standard method, following a 6-week daily intake of $22.5 \mathrm{~g}$ freeze-dried blueberry (1 cup fresh blueberries) (67). In addition, a recent crossover trial investigated the acute effects of high or low doses of freeze-dried blueberries (containing $310 \mathrm{mg}$ or $724 \mathrm{mg}$ TP) on plasma glucose 
in healthy young adults (68). Plasma glucose was determined using a capillary sampling method at baseline and at regular intervals up to $2.5 \mathrm{~h}$ postprandial. In the blueberry treatments, postprandial glycaemic response was significantly extended compared to the sugar-matched controls. Therefore, blueberry (poly)phenols may have the potential to slow postprandial glucose response (69).

No other studies measuring blood glucose or insulin sensitivity have found improvements following blueberry treatments $(49,54,62,66,70,71)$. The lack of findings on blood glucose or insulin levels following blueberry treatments may be largely due the use of alternative methods to the hyperinsulinemic-euglycemic clamp. For example, most studies use spot fasting glucose or insulin levels at baseline then at the end of the study. One study used a modified frequently sampled intravenous glucose tolerance test but found no effects following 6-weeks of blueberry consumption (54). In addition, only one study measured HbA1c levels after 8-weeks blueberry consumption, in 44 individuals with metabolic syndrome, finding no significant difference (62). This may be due to the short timeframe as HbA1c measures the average blood sugar levels over two to three months.

\section{Mechanisms of action on vascular function}

The mechanisms by which blueberries may positively affect vascular function are still largely unknown. Recent evidence, however, suggests that the vascular effects may be mediated by circulating phenolic metabolites derived from blueberry anthocyanins. The dose-response on FMD of isolated anthocyanins and anthocyanins consumed with blueberry are similar with almost identical ED50 values of $131 \mathrm{mg}$ and $119 \mathrm{mg}$ at $2 \mathrm{~h}$ after consumption, respectively (23). Fourteen and 21 of the circulating phenolic metabolites in plasma correlated with FMD increases at $2 \mathrm{~h}$ and at 28 days consumption of wild blueberry (150 mg anthocyanins acutely, or $300 \mathrm{mg}$ daily), respectively. Furthermore, data suggest that in humans acute FMD improvements go along with decreased neutrophil NADPH oxidase activity (52) and lead to differential expression (>1.2-fold) of 608 genes and 3 microRNAs, with Mir-181c showing a 13-fold increase in peripheral blood mononuclear cells (23). The patterns of 13 metabolites were independent predictors of gene expression changes and pathway enrichment analysis revealed significantly modulated biological processes involved in cell adhesion, migration, immune response, and cell differentiation. 
Importantly, when these metabolite profiles as observed in humans after blueberry consumption were injected into mice targeting similar plasma concentrations FMD significantly increased (23). This supports that circulating anthocyanin metabolome possesses biological activities and may be responsible for health effects ascribed to blueberry consumption. However, the biological activities and mechanisms of action of individual metabolites and their interaction in vivo are unknown (see recent review (17)). Evaluating the bioactivities of metabolites alone and together, analyzing their structure-activity relationship in well-designed and physiologically relevant experimental and human studies are needed to understand the mechanisms of how these metabolites affect vascular function.

\section{Conclusions}

Present evidence from both epidemiological and human intervention studies for the cardiovascular health benefits of blueberries is promising. The beneficial effects of blueberries on endothelial function, measured using FMD, are particularly clear. Blueberries may also be beneficial for other surrogate markers of future CVD risk such as blood pressure and HDLcholesterol. However, in current human intervention studies there is large heterogeneity between the study populations. For example, some studies use healthy individuals and others use individuals with metabolic syndrome or at high risk of CVD, which may be contributing to the differences in findings when investigating their effects on outcomes such as blood pressure. Differences in RCT durations may cause heterogeneity in other outcomes such as lipid profile and arterial stiffness. In addition, more studies are required investigating the effect of blueberries using gold standard techniques for measuring certain CVD risk markers, such as FMD, $24 \mathrm{~h}$ ambulatory blood pressure or the hyperinsulinemic-euglycemic clamp. There are very few studies addressing the ADME of blueberry (poly)phenols by measuring the subsequent metabolites found in the plasma, urine or faeces post-consumption, which is essential not only to monitor compliance but also to get mechanistic insights. The current evidence indicates that blueberry (poly)phenols have the potential to improve future cardiovascular health through various well-established surrogate markers. 


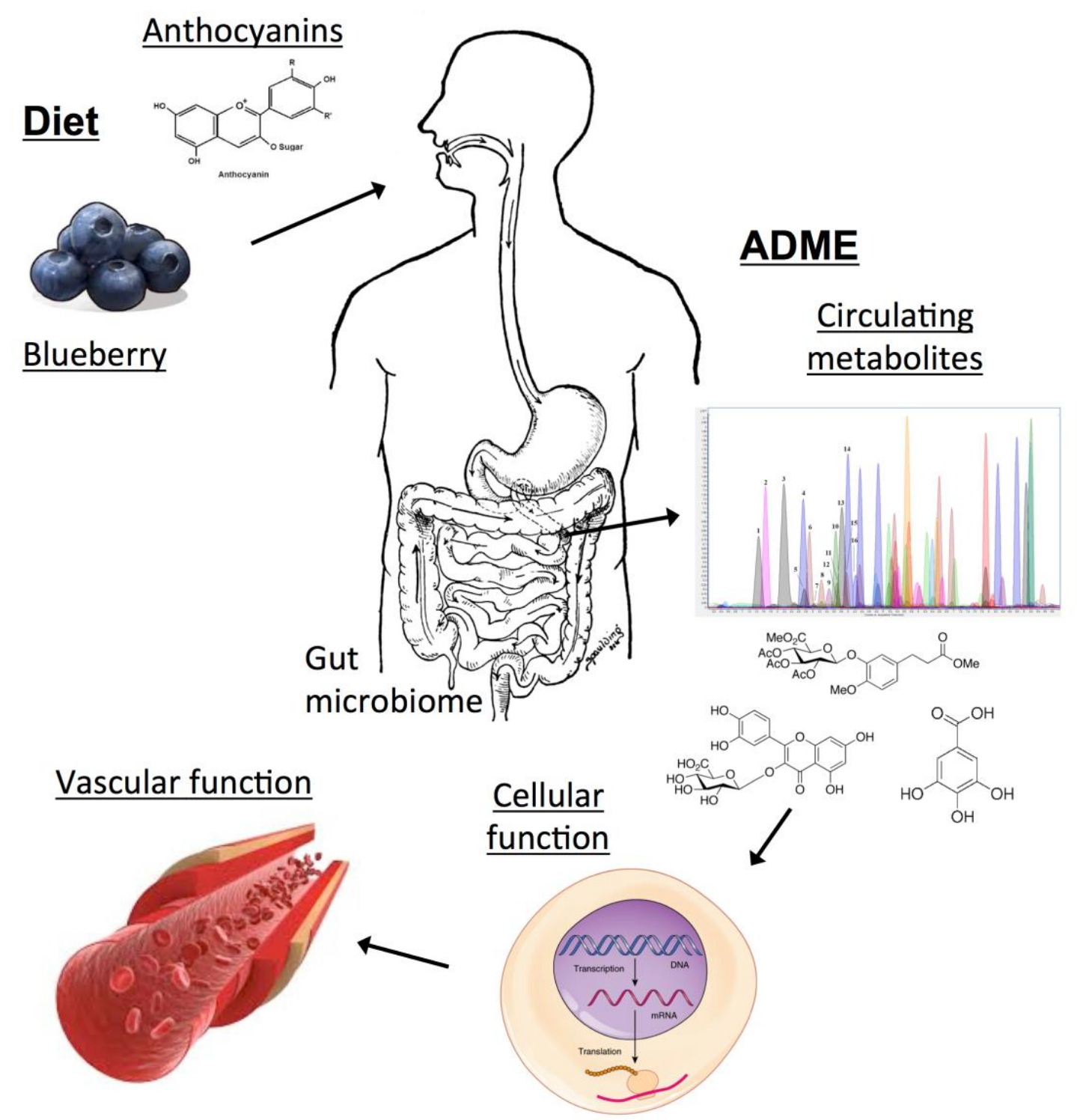

\section{Health}

Mechanisms of action

Figure 3- The main stages of importance when investigating the effects of blueberry anthocyanins on health outcomes. 


\section{References}

1. Rodriguez-Mateos A, Heiss C, Borges G, Crozier A. Berry (poly)phenols and cardiovascular health. Journal of agricultural and food chemistry. 2014;62(18):3842-51.

2. Zhu Y, Sun J, Lu W, Wang X, Wang X, Han Z, et al. Effects of blueberry supplementation on blood pressure: a systematic review and meta-analysis of randomized clinical trials. J Hum Hypertens. 2017;31(3):165-71.

3. Heneghan C, Kiely M, Lyons J, Lucey A. The Effect of Berry-Based Food Interventions on Markers of Cardiovascular and Metabolic Health: A Systematic Review of Randomized Controlled Trials. Mol Nutr Food Res. 2018;62(1).

4. Yang L, Ling W, Du Z, Chen Y, Li D, Deng S, et al. Effects of Anthocyanins on Cardiometabolic Health: A Systematic Review and Meta-Analysis of Randomized Controlled Trials. Adv Nutr. 2017;8(5):684-93.

5. Fairlie-Jones L, Davison K, Fromentin E, Hill AM. The Effect of Anthocyanin-Rich Foods or Extracts on Vascular Function in Adults: A Systematic Review and Meta-Analysis of Randomised Controlled Trials. Nutrients. 2017;9(8).

6. Martini D, Marino M, Angelino D, Del Bo C, Del Rio D, Riso P, et al. Role of berries in vascular function: a systematic review of human intervention studies. Nutr Rev. 2019.

7. Huang H, Chen G, Liao D, Zhu Y, Xue X. Effects of Berries Consumption on Cardiovascular Risk Factors: A Meta-analysis with Trial Sequential Analysis of Randomized Controlled Trials. Sci Rep. 2016;6:23625.

8. Luis A, Domingues F, Pereira L. Association between berries intake and cardiovascular diseases risk factors: a systematic review with meta-analysis and trial sequential analysis of randomized controlled trials. Food Funct. 2018;9(2):740-57.

9. Michalska A, Lysiak G. Bioactive Compounds of Blueberries: Post-Harvest Factors Influencing the Nutritional Value of Products. Int J Mol Sci. 2015;16(8):18642-63.

10. Rodriguez-Mateos A, Cifuentes-Gomez T, Tabatabaee S, Lecras C, Spencer JP. Procyanidin, anthocyanin, and chlorogenic acid contents of highbush and lowbush blueberries. J Agric Food Chem. 2012;60(23):5772-8.

11. Castañeda-Ovando A, Pacheco-Hernández MdL, Páez-Hernández ME, Rodríguez JA, Galán-Vidal CA. Chemical studies of anthocyanins: A review. Food Chemistry. 2009;113(4):859-

71.

12. Wu X, Prior RL. Identification and characterization of anthocyanins by high-performance liquid chromatography-electrospray ionization-tandem mass spectrometry in common foods in the United States: vegetables, nuts, and grains. J Agric Food Chem. 2005;53(8):3101-13.

13. Kalt W, McDonald JE, Ricker RD, Lu X. Anthocyanin content and profile within and among blueberry species. Can J Plant Sci. 1999;79(4):617-23.

14. Neveu V, Perez-Jimenez J, Vos F, Crespy V, du Chaffaut L, Mennen L, et al. PhenolExplorer: an online comprehensive database on polyphenol contents in foods. DatabaseOxford. 2010.

15. Wu XL, Beecher GR, Holden JM, Haytowitz DB, Gebhardt SE, Prior RL. Concentrations of anthocyanins in common foods in the United States and estimation of normal consumption. Journal of agricultural and food chemistry. 2006;54(11):4069-75. 
16. Gu LW, Kelm MA, Hammerstone JF, Beecher G, Holden J, Haytowitz D, et al. Concentrations of proanthocyanidins in common foods and estimations of normal consumption. Journal of Nutrition. 2004;134(3):613-7.

17. Cutler BR, Petersen C, Anandh Babu PV. Mechanistic insights into the vascular effects of blueberries: Evidence from recent studies. Mol Nutr Food Res. 2017;61(6).

18. You Q, Wang BW, Chen F, Huang ZL, Wang X, Luo PG. Comparison of anthocyanins and phenolics in organically and conventionally grown blueberries in selected cultivars. Food Chemistry. 2011;125(1):201-8.

19. Deng Y, Yang GY, Yue J, Qian BJ, Liu ZM, Wang DF, et al. Influences of ripening stages and extracting solvents on the polyphenolic compounds, antimicrobial and antioxidant activities of blueberry leaf extracts. Food Control. 2014;38:184-91.

20. Howard LR, Prior RL, Liyanage R, Lay JO. Processing and Storage Effect on Berry Polyphenols: Challenges and Implications for Bioactive Properties. Journal of agricultural and food chemistry. 2012;60(27):6678-93.

21. Weingerl V, Strlic M, Kocar D. Comparison of Methods for Determination of Polyphenols in Wine by HPLC-UV/VIS, LC/MS/MS and Spectrophotometry. Acta Chim Slov. 2009;56(3):698703.

22. Ottaviani JI, Fong RY, Borges G, Schroeter H, Crozier A. Use of LC-MS for the quantitative analysis of (poly)phenol metabolites does not necessarily yield accurate results: Implications for assessing existing data and conducting future research. Free Radical Bio Med. 2018;124:97-103. 23. Rodriguez-Mateos A, Istas G, Boschek L, Feliciano RP, Mills CE, Boby C, et al. Circulating Anthocyanin Metabolites Mediate Vascular Benefits of Blueberries: Insights From Randomized Controlled Trials, Metabolomics, and Nutrigenomics. J Gerontol A Biol Sci Med Sci. 2019;74(7):967-76.

24. Kay CD, Mazza GJ, Holub BJ. Anthocyanins exist in the circulation primarily as metabolites in adult men. J Nutr. 2005;135(11):2582-8.

25. Manach C, Williamson G, Morand C, Scalbert A, Remesy C. Bioavailability and bioefficacy of polyphenols in humans. I. Review of 97 bioavailability studies. Am J Clin Nutr. 2005;81(1 Suppl):230S-42S.

26. McGhie TK, Walton MC. The bioavailability and absorption of anthocyanins: towards a better understanding. Mol Nutr Food Res. 2007;51(6):702-13.

27. Vitaglione P, Donnarumma G, Napolitano A, Galvano F, Gallo A, Scalfi L, et al. Protocatechuic acid is the major human metabolite of cyanidin-glucosides. The Journal of nutrition. 2007;137(9):2043-8.

28. Czank C, Cassidy A, Zhang Q, Morrison DJ, Preston T, Kroon PA, et al. Human metabolism and elimination of the anthocyanin, cyanidin-3-glucoside: a (13)C-tracer study. Am J Clin Nutr. 2013;97(5):995-1003.

29. de Ferrars RM, Czank C, Zhang Q, Botting NP, Kroon PA, Cassidy A, et al. The pharmacokinetics of anthocyanins and their metabolites in humans. Br J Pharmacol. 2014;171(13):3268-82.

30. Selma MV, Espin JC, Tomas-Barberan FA. Interaction between phenolics and gut microbiota: role in human health. J Agric Food Chem. 2009;57(15):6485-501.

31. Feliciano RP, Istas G, Heiss C, Rodriguez-Mateos A. Plasma and Urinary Phenolic Profiles after Acute and Repetitive Intake of Wild Blueberry. Molecules. 2016;21(9). 
32. Manach C, Milenkovic D, Van de Wiele T, Rodriguez-Mateos A, de Roos B, Garcia-Conesa $M T$, et al. Addressing the inter-individual variation in response to consumption of plant food bioactives: Towards a better understanding of their role in healthy aging and cardiometabolic risk reduction. Molecular Nutrition \& Food Research. 2017;61(6).

33. Jennings A, Welch AA, Fairweather-Tait SJ, Kay C, Minihane AM, Chowienczyk P, et al. Higher anthocyanin intake is associated with lower arterial stiffness and central blood pressure in women. Am J Clin Nutr. 2012;96(4):781-8.

34. Cassidy A. Berry anthocyanin intake and cardiovascular health. Mol Aspects Med. 2017.

35. Rissanen TH, Voutilainen S, Virtanen JK, Venho B, Vanharanta M, Mursu J, et al. Low intake of fruits, berries and vegetables is associated with excess mortality in men: the Kuopio Ischaemic Heart Disease Risk Factor (KIHD) Study. The Journal of nutrition. 2003;133(1):199204.

36. Mink PJ, Scrafford CG, Barraj LM, Harnack L, Hong CP, Nettleton JA, et al. Flavonoid intake and cardiovascular disease mortality: a prospective study in postmenopausal women. Am J Clin Nutr. 2007;85(3):895-909.

37. Wang X, Ouyang YY, Liu J, Zhao G. Flavonoid intake and risk of CVD: a systematic review and meta-analysis of prospective cohort studies. The British journal of nutrition. 2014;111(1):111.

38. Grosso G, Micek A, Godos J, Pajak A, Sciacca S, Galvano F, et al. Dietary Flavonoid and Lignan Intake and Mortality in Prospective Cohort Studies: Systematic Review and DoseResponse Meta-Analysis. Am J Epidemiol. 2017;185(12):1304-16.

39. Cassidy A, Mukamal KJ, Liu L, Franz M, Eliassen AH, Rimm EB. High anthocyanin intake is associated with a reduced risk of myocardial infarction in young and middle-aged women. Circulation. 2013;127(2):188-96.

40. Organization WH. International Classification of Diseases, 9th rev. (ICD-9). 1977.

41. Rodriguez-Mateos A, Vauzour D, Krueger CG, Shanmuganayagam D, Reed J, Calani L, et al. Bioavailability, bioactivity and impact on health of dietary flavonoids and related compounds: an update. Arch Toxicol. 2014;88(10):1803-53.

42. USDA. USDA database for the flavonoid content of selected foods release. 2007;21st edn USDA, Belstville.

43. Dragsted LO, Gao Q, Scalbert A, Vergeres G, Kolehmainen M, Manach C, et al. Validation of biomarkers of food intake-critical assessment of candidate biomarkers. Genes Nutr. 2018;13:14.

44. Anderson TJ. Arterial stiffness or endothelial dysfunction as a surrogate marker of vascular risk. Can J Cardiol. 2006;22 Suppl B:72B-80B.

45. Heiss $C$, Rodriguez-Mateos A, Kelm M. Central role of eNOS in the maintenance of endothelial homeostasis. Antioxid Redox Signal. 2015;22(14):1230-42.

46. Shechter M, Shechter A, Koren-Morag N, Feinberg MS, Hiersch L. Usefulness of brachial artery flow-mediated dilation to predict long-term cardiovascular events in subjects without heart disease. Am J Cardiol. 2014;113(1):162-7.

47. Ras RT, Streppel MT, Draijer R, Zock PL. Flow-mediated dilation and cardiovascular risk prediction: a systematic review with meta-analysis. Int J Cardiol. 2013;168(1):344-51. 
48. Inaba Y, Chen JA, Bergmann SR. Prediction of future cardiovascular outcomes by flowmediated vasodilatation of brachial artery: a meta-analysis. Int J Cardiovasc Imaging. 2010;26(6):631-40.

49. Stote KS, Sweeney MI, Kean T, Baer DJ, Novotny JA, Shakerley NL, et al. The effects of $100 \%$ wild blueberry (Vaccinium angustifolium) juice consumption on cardiometablic biomarkers: a randomized, placebo-controlled, crossover trial in adults with increased risk for type 2 diabetes. BMC Nutrition. 2017;3(1):45.

50. Del Bo C, Riso P, Campolo J, Moller P, Loft S, Klimis-Zacas D, et al. A single portion of blueberry (Vaccinium corymbosum $\mathrm{L}$ ) improves protection against DNA damage but not vascular function in healthy male volunteers. Nutrition research (New York, NY). 2013;33(3):220-7.

51. Del Bo C, Deon V, Campolo J, Lanti C, Parolini M, Porrini M, et al. A serving of blueberry (V. corymbosum) acutely improves peripheral arterial dysfunction in young smokers and nonsmokers: two randomized, controlled, crossover pilot studies. Food Funct. 2017;8(11):4108-17. 52. Rodriguez-Mateos A, Rendeiro C, Bergillos-Meca T, Tabatabaee S, George TW, Heiss C, et al. Intake and time dependence of blueberry flavonoid-induced improvements in vascular function: a randomized, controlled, double-blind, crossover intervention study with mechanistic insights into biological activity. Am J Clin Nutr. 2013;98(5):1179-91.

53. Curtis PJ, van der Velpen V, Berends L, Jennings A, Feelisch M, Umpleby AM, et al. Blueberries improve biomarkers of cardiometabolic function in participants with metabolic syndrome-results from a 6-month, double-blind, randomized controlled trial. Am J Clin Nutr. 2019;109(6):1535-45.

54. Stull AJ, Cash KC, Champagne CM, Gupta AK, Boston R, Beyl RA, et al. Blueberries improve endothelial function, but not blood pressure, in adults with metabolic syndrome: a randomized, double-blind, placebo-controlled clinical trial. Nutrients. 2015;7(6):4107-23. 55. Del Bo C, Porrini M, Fracassetti D, Campolo J, Klimis-Zacas D, Riso P. A single serving of blueberry (V. corymbosum) modulates peripheral arterial dysfunction induced by acute cigarette smoking in young volunteers: a randomized-controlled trial. Food Funct. 2014;5(12):3107-16.

56. Rodriguez-Mateos A, Del Pino-Garcia R, George TW, Vidal-Diez A, Heiss C, Spencer JP. Impact of processing on the bioavailability and vascular effects of blueberry (poly)phenols. Mol Nutr Food Res. 2014;58(10):1952-61.

57. Riso P, Klimis-Zacas D, Del Bo C, Martini D, Campolo J, Vendrame S, et al. Effect of a wild blueberry (Vaccinium angustifolium) drink intervention on markers of oxidative stress, inflammation and endothelial function in humans with cardiovascular risk factors. European journal of nutrition. 2013;52(3):949-61.

58. Franklin SS, Wong ND. Hypertension and Cardiovascular Disease: Contributions of the Framingham Heart Study. Global Heart. 2013;8(1):49-57.

59. Messerli FH, Fischer U, Rimoldi SF, Bangalore S. Hypertension control and cardiovascular disease. Lancet. 2017;389(10065):153.

60. Ettehad D, Emdin CA, Kiran A, Anderson SG, Callender T, Emberson J, et al. Blood pressure lowering for prevention of cardiovascular disease and death: a systematic review and meta-analysis. Lancet. 2016;387(10022):957-67. 
61. Johnson SA, Figueroa A, Navaei N, Wong A, Kalfon R, Ormsbee LT, et al. Daily blueberry consumption improves blood pressure and arterial stiffness in postmenopausal women with pre- and stage 1-hypertension: a randomized, double-blind, placebo-controlled clinical trial. Journal of the Academy of Nutrition and Dietetics. 2015;115(3):369-77.

62. Basu A, Du M, Leyva MJ, Sanchez K, Betts NM, Wu M, et al. Blueberries decrease cardiovascular risk factors in obese men and women with metabolic syndrome. J Nutr. 2010;140(9):1582-7.

63. McAnulty SR, McAnulty LS, Morrow JD, Khardouni D, Shooter L, Monk J, et al. Effect of daily fruit ingestion on angiotensin converting enzyme activity, blood pressure, and oxidative stress in chronic smokers. Free Radic Res. 2005;39(11):1241-8.

64. Zhu Y, Miao Y, Meng Z, Zhong Y. Effects of Vaccinium Berries on Serum Lipids: A MetaAnalysis of Randomized Controlled Trials. Evid Based Complement Alternat Med. 2015;2015:790329.

65. Cheatham CL, Vazquez-Vidal I, Medlin A, Voruganti VS. Blueberry Consumption Affects Serum Uric Acid Concentrations in Older Adults in a Sex-Specific Manner. Antioxidants (Basel, Switzerland). 2016;5(4).

66. Nyberg S, Gerring E, Gjellan S, Vergara M, Lindstrom T, Nystrom FH. Effects of exercise with or without blueberries in the diet on cardio-metabolic risk factors: an exploratory pilot study in healthy subjects. Upsala journal of medical sciences. 2013;118(4):247-55.

67. Stull AJ, Cash KC, Johnson WD, Champagne CM, Cefalu WT. Bioactives in blueberries improve insulin sensitivity in obese, insulin-resistant men and women. J Nutr.

2010;140(10):1764-8.

68. Bell L, Lamport DJ, Butler LT, Williams CM. A study of glycaemic effects following acute anthocyanin-rich blueberry supplementation in healthy young adults. Food Funct. 2017;8(9):3104-10.

69. Rozendaal YJ, Maas AH, van Pul C, Cottaar EJ, Haak HR, Hilbers PA, et al. Model-based analysis of postprandial glycemic response dynamics for different types of food. Clinical Nutrition Experimental. 2018;19:32-45.

70. Ono-Moore KD, Snodgrass RG, Huang S, Singh S, Freytag TL, Burnett DJ, et al. Postprandial Inflammatory Responses and Free Fatty Acids in Plasma of Adults Who Consumed a Moderately High-Fat Breakfast with and without Blueberry Powder in a Randomized PlaceboControlled Trial. J Nutr. 2016;146(7):1411-9.

71. Blacker BC, Snyder SM, Eggett DL, Parker TL. Consumption of blueberries with a highcarbohydrate, low-fat breakfast decreases postprandial serum markers of oxidation. Br J Nutr. 2013;109(9):1670-7.

72. Johnson SA, Feresin RG, Navaei N, Figueroa A, Elam ML, Akhavan NS, et al. Effects of daily blueberry consumption on circulating biomarkers of oxidative stress, inflammation, and antioxidant defense in postmenopausal women with pre- and stage 1-hypertension: a randomized controlled trial. Food Funct. 2017;8(1):372-80.

73. McAnulty LS, Nieman DC, Dumke CL, Shooter LA, Henson DA, Utter AC, et al. Effect of blueberry ingestion on natural killer cell counts, oxidative stress, and inflammation prior to and after $2.5 \mathrm{~h}$ of running. Applied Physiology Nutrition and Metabolism-Physiologie Appliquee Nutrition Et Metabolisme. 2011;36(6):976-84. 
74. Nair AR, Mariappan N, Stull AJ, Francis J. Blueberry supplementation attenuates oxidative stress within monocytes and modulates immune cell levels in adults with metabolic syndrome: a randomized, double-blind, placebo-controlled trial. Food Funct. 2017;8(11):411828.

\section{TABLES}

Table 1. Nutrient composition of blueberries (23)

\begin{tabular}{lc}
\hline Nutrients & Amount per 100g \\
\hline Dietary fibre (g) & 40 \\
Potassium (mg) & 618 \\
Fructose (g) & 33 \\
Total beta carotene (IU) & 527 \\
Vitamin C (mg) & 15 \\
Calcium (mg) & 155 \\
Iron (mg & 5.3 \\
Vitamin E (IU) & 3.5 \\
Vitamin B1 (mg & 0.27 \\
Vitamin B2 (mg) & 0.09 \\
Vitamin B6 (mg) & 0.18 \\
Phosphorus (mg) & 117 \\
Magnesium (mg) & 59 \\
Zinc (mg) & 6.09 \\
Manganese (mg) & 26 \\
Niacin (mg) & 5.5 \\
\hline
\end{tabular}


Table 2. Table of randomised-controlled trials investigating the effects of blueberries on markers of cardiovascular disease risk

\begin{tabular}{|c|c|c|c|c|c|c|c|c|}
\hline Reference & Study design & $\begin{array}{c}\text { Study } \\
\text { subjects }\end{array}$ & $\begin{array}{l}\text { Health status } \\
\text { of volunteers }\end{array}$ & Blueberry treatment & $\begin{array}{c}\text { ACN } \\
\text { (mg/dose) }\end{array}$ & Control & Duration & Significant findings \\
\hline $\begin{array}{l}\text { Basu et al. } \\
(2010)(62)\end{array}$ & $\begin{array}{l}\text { Randomised, } \\
\text { single-blinded, } \\
\text { parallel, } \\
\text { controlled trial }\end{array}$ & $\begin{array}{l}48 \text { men and } \\
\text { women } \\
\text { (mean age: } \\
50 \pm 3 \text { ) }\end{array}$ & $\begin{array}{l}\text { Metabolic } \\
\text { syndrome }\end{array}$ & $\begin{array}{l}50 \text { g freeze-fried BB } \\
\text { + vanilla extract or } \\
\text { Splenda }\end{array}$ & 742 & $\begin{array}{l}\text { Water to } \\
\text { match the } \\
\text { fluid intake in } \\
\text { the treatment } \\
\text { group }(960 \mathrm{ml})\end{array}$ & $\begin{array}{l}\text { Daily } \\
\text { consumpti } \\
\text { on: } 8 \\
\text { weeks }\end{array}$ & $\begin{array}{l}\text { BP decreased in blueberry group } \\
\text { compared with the control group } \\
\text { by }-7.8 \text { and }-2.5 \mathrm{mmHg} \text { respectively. } \\
\text { Ox-LDL decrease in blueberry group }\end{array}$ \\
\hline $\begin{array}{l}\text { Bell et al. } \\
\text { (2017) (68) }\end{array}$ & $\begin{array}{l}\text { Randomised, } \\
\text { double-blind, } \\
\text { crossover trial }\end{array}$ & $\begin{array}{l}16 \text { young } \\
\text { adults } \\
\text { (mean age: } \\
24 \pm 5 \text { ) }\end{array}$ & $\begin{array}{l}\text { Healthy (BMI: } \\
23.7 \pm 3.6 \\
\mathrm{~kg} / \mathrm{m}^{2} \text { ) }\end{array}$ & $\begin{array}{l}\text { Freeze-dried BB: low } \\
\text { dose } 34 \mathrm{~g} \text {, low dose } \\
34 \mathrm{~g}+\text { sugar, high } \\
\text { dose } 80 \mathrm{~g}+\text { sugar }\end{array}$ & $310,310,724$ & $\begin{array}{l}\text { No-added } \\
\text { sugar control } \\
\text { or sugar- } \\
\text { matched } \\
\text { control }\end{array}$ & $\begin{array}{l}\text { Acute: } 0, \\
15,30,45 \\
60,90 \\
120 \text { and } \\
150 \text { mins }\end{array}$ & $\begin{array}{l}\text { Blueberries extended the } \\
\text { postprandial glycaemic response. } \\
\text { Blood glucose remained elevated } \\
\text { for } 2 \mathrm{~h} \text { in the } 724 \mathrm{mg} \text { anthocyanin } \\
\text { dose and } 1.5 \mathrm{~h} \text { in the } 310 \mathrm{mg} \text { dose }\end{array}$ \\
\hline $\begin{array}{l}\text { Blacker et } \\
\text { al. (2013) } \\
\text { (71) }\end{array}$ & $\begin{array}{l}\text { Randomised, } \\
\text { crossover, } \\
\text { controlled trial }\end{array}$ & $\begin{array}{l}15 \text { men and } \\
\text { women } \\
\text { (mean age: } \\
22 \text { ) }\end{array}$ & $\begin{array}{l}\text { Healthy (BMI: } \\
23.6 \text {, range: } \\
20-28 \mathrm{~kg} / \mathrm{m}^{2} \text { ) }\end{array}$ & $\begin{array}{c}5.83 \mathrm{~g} \text { or } 12.5 \mathrm{~g} \\
\text { freeze-dried BB } \\
\text { powder + high-CHO } \\
\text { low-fat meal }\end{array}$ & 75 and 161 & $\begin{array}{l}\text { Sugar and } \\
\text { Vitamin C } \\
\text { matched }+ \\
\text { high-CHO low- } \\
\text { fat meal }\end{array}$ & $\begin{array}{c}\text { Acute: } \\
\text { baseline, } \\
\text { 1, } 2 \text { and } 3 \\
\mathrm{~h}\end{array}$ & $\begin{array}{l}\text { Serum ORAC was higher in the high } \\
\text { blueberry dose group compared to } \\
\text { control up to } 2 \mathrm{~h} \text { postprandially. } \\
\text { Serum LO lag time showed a } \\
\text { significant trend over } 3 \mathrm{~h} \text { for both } \\
\text { blueberry doses }\end{array}$ \\
\hline $\begin{array}{l}\text { Cheatham } \\
\text { et al. } \\
\text { (2016) (65) }\end{array}$ & $\begin{array}{c}\text { Randomised, } \\
\text { double-blind, } \\
\text { parallel, } \\
\text { controlled trial }\end{array}$ & $\begin{array}{l}113 \text { men } \\
\text { and women } \\
\text { (mean age: } \\
73 \pm 4 \text { ) }\end{array}$ & $\begin{array}{l}\text { Healthy with } \\
\qquad \mathrm{MCl}\end{array}$ & $\begin{array}{c}35 \mathrm{~g} \text { freeze dried BB } \\
\text { powder }\end{array}$ & N/A & $\begin{array}{l}\text { Calorie, sugar, } \\
\text { taste and } \\
\text { colour } \\
\text { matched }\end{array}$ & $\begin{array}{l}\text { Daily } \\
\text { consumpti } \\
\text { on: } 6 \\
\text { months }\end{array}$ & $\begin{array}{l}3 \text { months after consumption serum } \\
\text { uric acid decreased in the blueberry } \\
\text { group but not after } 6 \text { months }\end{array}$ \\
\hline $\begin{array}{l}\text { Curtis et } \\
\text { al. (2019) } \\
\text { (53) }\end{array}$ & $\begin{array}{c}\text { Randomised, } \\
\text { double-blind, } \\
\text { parallel, } \\
\text { controlled trial }\end{array}$ & $\begin{array}{l}115 \text { men } \\
\text { and women } \\
\text { (mean age: } \\
63 \pm 7\end{array}$ & $\begin{array}{l}\text { Overweight } \\
\text { and obese ( } \geq \\
\left.25 \mathrm{~kg} / \mathrm{m}^{2}\right) \\
\text { with } \\
\text { metabolic } \\
\text { syndrome }\end{array}$ & $\begin{array}{l}26 \mathrm{~g} \text { freeze dried BB } \\
\text { powder, or } 13 \mathrm{~g} \\
\text { placebo }+13 \mathrm{~g} \mathrm{BB} \\
\text { powder, or } 26 \mathrm{~g} \\
\text { placebo }\end{array}$ & $\begin{array}{c}364 \mathrm{~g}, 182 \mathrm{~g}, 0 \\
\mathrm{~g}\end{array}$ & $\begin{array}{l}\text { Isocaloric, } \\
\text { carbohydrate- } \\
\text { matched } \\
\text { control }\end{array}$ & $\begin{array}{l}\text { Daily } \\
\text { consumpti } \\
\text { on for } 6 \\
\text { months }\end{array}$ & $\begin{array}{l}\text { Improved FMD }(+1.45 \%) \text { and } \\
\text { reduced augmentation index (- } \\
2.24 \%) \text { following the highest dose } \\
\text { of } \mathrm{BB} \text {, as well as attenuated } \\
\text { guanosine monophosphate } \\
\text { concentrations. }\end{array}$ \\
\hline
\end{tabular}




\begin{tabular}{|c|c|c|c|c|c|c|c|c|}
\hline $\begin{array}{l}\text { Del Bo et } \\
\text { al. }(2013) \\
\quad(50)\end{array}$ & $\begin{array}{l}\text { Randomised, } \\
\text { single-blind, } \\
\text { crossover, } \\
\text { controlled trial }\end{array}$ & $\begin{array}{l}10 \text { males } \\
\text { (mean age: } \\
21 \pm 2 \text { ) }\end{array}$ & $\begin{array}{l}\text { Healthy (BMI: } \\
23 \pm 2 \mathrm{~kg} / \mathrm{m}^{2} \text { ) }\end{array}$ & $\begin{array}{l}300 \mathrm{~g} \text { BB processed: } \\
\text { thawed }\left(3 \mathrm{~h} \text { at } 20^{\circ} \mathrm{C}\right) \\
\text { and homogenized }\end{array}$ & 348 & $\begin{array}{l}\text { Control jelly } \\
\text { matched for } \\
\text { sugars }\end{array}$ & $\begin{array}{l}\text { acute: } 24 \\
\text { hours } \\
\text { (measure } \\
\text { d } 1,2 \text { and } \\
24 \text { h) }\end{array}$ & $\begin{array}{l}\text { Reduction in } \mathrm{H} 2 \mathrm{O} 2 \text {-induced DNA } \\
\text { damage } 1 \mathrm{~h} \text { post consumption of } \\
\text { blueberry }\end{array}$ \\
\hline $\begin{array}{l}\text { Del Bo et } \\
\text { al. (2014) } \\
\quad(55)\end{array}$ & $\begin{array}{l}\text { Randomised, } \\
\text { single-blind, } \\
\text { crossover, } \\
\text { controlled trial }\end{array}$ & $\begin{array}{l}16 \text { males } \\
\text { (mean age: } \\
24 \pm 3 \text { ) }\end{array}$ & $\begin{array}{c}\text { Healthy } \\
\text { smokers } \sim 15 \\
\text { cigarettes per } \\
\text { day }(\mathrm{BMl}: 23 \pm \\
\left.2 \mathrm{~kg} / \mathrm{m}^{2}\right)\end{array}$ & 300 g BB + smoking & 348 & $\begin{array}{l}\text { Smoking } \\
\text { treatment or } \\
\text { Smoking }+ \\
\text { sugar water }\end{array}$ & $\begin{array}{l}\text { acute: } 2 \\
\text { hours } \\
\text { (measure } \\
\text { d } 100,105 \\
\text { and } 120 \\
\text { mins) }\end{array}$ & $\begin{array}{l}\text { Blueberries counteracted the } \\
\text { increase in SBP and attenuated the } \\
\text { reduction in RHI that occurs after } \\
\text { smoking }\end{array}$ \\
\hline $\begin{array}{l}\text { Del Bo et } \\
\text { al. (2017) } \\
\mathbf{( 5 1 )}\end{array}$ & $\begin{array}{l}\text { Randomised, } \\
\text { crossover, } \\
\text { controlled trial }\end{array}$ & $\begin{array}{l}24 \text { males (12 } \\
\text { smokers, } 12 \\
\text { non- } \\
\text { smokers. } \\
\text { Mean age: } \\
24 \pm 1)\end{array}$ & $\begin{array}{l}\text { Both groups } \\
\text { have } \\
\text { peripheral } \\
\text { arterial } \\
\text { dysfunction } \\
(\mathrm{RHI}<1.67) \\
(\mathrm{BMI} 22.5 \pm \\
\left.1.2 \mathrm{~kg} / \mathrm{m}^{2}\right)\end{array}$ & $\begin{array}{l}300 \mathrm{~g} \mathrm{BB} \text { with or } \\
\text { without smoking }\end{array}$ & 309 & $\begin{array}{l}\text { Non-smokers: } \\
300 \text { ml sugar } \\
\text { water. } \\
\text { Smokers: } \\
\text { smoking } \\
\text { treatment or } \\
300 \text { ml sugar } \\
\text { water + } \\
\text { smoking }\end{array}$ & $\begin{array}{c}\text { Non- } \\
\text { smokers: } \\
0,100, \\
120 \text { mins. } \\
\text { Smokers: } \\
0,100, \\
105 \text { and } \\
120 \text { mins } \\
\text { (smoking } \\
\text { at } 105 \\
\text { mins) }\end{array}$ & $\begin{array}{c}\text { Non-smokers: RHI increased in the } \\
\text { blueberry treatment compared to } \\
\text { control. Smokers: both control and } \\
\text { blueberry treatment improved RHI } \\
\text { compared with the smoking only } \\
\text { treatment }\end{array}$ \\
\hline $\begin{array}{l}\text { Johnson et } \\
\text { al. (2015) } \\
\quad(61)\end{array}$ & $\begin{array}{l}\text { Randomised, } \\
\text { double-blind, } \\
\text { parallel, } \\
\text { controlled trial }\end{array}$ & $\begin{array}{c}48 \\
\text { postmenopa } \\
\text { usal women } \\
\text { (mean age: } \\
\text { blueberry } \\
\text { group } 60 \pm \\
5 \text {; control } 57 \\
\pm 5 \text { ) }\end{array}$ & $\begin{array}{c}\text { Pre- and } \\
\text { stage- } 1 \\
\text { hypertensives. } \\
\text { BMl: } \\
\text { blueberry } \\
\text { group } 30 \pm 6 \\
\mathrm{~kg} / \mathrm{m}^{2} ; \text { control } \\
33 \pm 7 \mathrm{~kg} / \mathrm{m}^{2} \text {. }\end{array}$ & $\begin{array}{l}22 \mathrm{~g} \text { freeze-dried } \mathrm{BB} \\
\text { powder }\end{array}$ & 469 & $\begin{array}{l}22 \mathrm{~g} \\
\text { macronutrient } \\
\text {-matched } \\
\text { control } \\
\text { powder }\end{array}$ & $\begin{array}{l}\text { Daily } \\
\text { consumpti } \\
\text { on: } 8 \\
\text { weeks } \\
\text { (measure } \\
\text { d at } 4 \text { and } \\
8 \text { weeks) }\end{array}$ & $\begin{array}{l}\text { BP reduced at } 8 \text { weeks in the } \\
\text { blueberry group (SBP by }-7 \mathrm{mmHg} \text {, } \\
\text { DBP by }-5 \mathrm{mmHg} \text { ). baPWV reduced } \\
\text { in blueberry group but cfPWV did } \\
\text { not. SOD increased in both groups }\end{array}$ \\
\hline $\begin{array}{l}\text { Johnson et } \\
\text { al. (2017) } \\
\text { (72) }\end{array}$ & $\begin{array}{l}\text { Randomised, } \\
\text { double-blind, } \\
\text { parallel, } \\
\text { controlled trial }\end{array}$ & $\begin{array}{l}48 \\
\text { postmenopa } \\
\text { usal women } \\
\text { (mean age: } \\
\text { blueberry } \\
\text { group } 60 \pm\end{array}$ & $\begin{array}{l}\text { Pre- and } \\
\text { stage-1 } \\
\text { hypertensives } \\
\text { BMI: } \\
\text { blueberry } \\
\text { group } 30 \pm 6\end{array}$ & $\begin{array}{l}22 \mathrm{~g} \text { freeze-dried BB } \\
\text { powder }+240 \mathrm{ml} \\
\text { water }\end{array}$ & 469 & $\begin{array}{l}\text { 22g control } \\
\text { powder: } \\
\text { sugars, } \\
\text { flavourings } \\
\text { and colouring, } \\
\text { citric acid and }\end{array}$ & $\begin{array}{l}\text { Daily } \\
\text { consumpti } \\
\text { on for } 8 \\
\text { weeks }\end{array}$ & $\begin{array}{l}\text { 8-OHdG levels were lower in } \\
\text { blueberry compared to control at } 4 \\
\text { weeks but not at } 8 \text { weeks. }\end{array}$ \\
\hline
\end{tabular}




\begin{tabular}{|c|c|c|c|c|c|c|c|c|}
\hline & & $\begin{array}{l}5 \text {; control } 57 \\
\pm 5)\end{array}$ & $\begin{array}{l}\mathrm{kg} / \mathrm{m}^{2} ; \text { control } \\
33 \pm 7 \mathrm{~kg} / \mathrm{m}^{2}\end{array}$ & & & $\begin{array}{l}\text { silica dioxide + } \\
\text { water }\end{array}$ & & \\
\hline $\begin{array}{l}\text { McAnulty } \\
\text { et al. } \\
\text { (2005) (63) }\end{array}$ & $\begin{array}{l}\text { Randomised, } \\
\text { parallel, } \\
\text { controlled trial }\end{array}$ & $\begin{array}{l}20 \text { men and } \\
\text { women } \\
\text { (mean age: } \\
\text { blueberry } \\
\text { group } 26 \pm \\
3 \text {; control } 29 \\
\pm 4 \text { ) }\end{array}$ & $\begin{array}{l}\text { Smokers (min } \\
1 \text { pack/day for } \\
>1 \text { year). BMI: } \\
\text { blueberry } \\
\text { group } 30 \pm 3 \\
\mathrm{~kg} / \mathrm{m}^{2} ; \text { control } \\
29 \pm 3 \mathrm{~kg} / \mathrm{m}^{2} .\end{array}$ & $251 \mathrm{~g}$ fresh $\mathrm{BB}$ & N/A & $\begin{array}{c}\text { Normal } \\
\text { dietary habits }\end{array}$ & $\begin{array}{l}\text { Daily } \\
\text { consumpti } \\
\text { on: } 3 \\
\text { weeks }\end{array}$ & $\begin{array}{l}\text { No change in BP, F2-isoprostane } \\
\text { concentration or ACE activity }\end{array}$ \\
\hline $\begin{array}{l}\text { McAnulty } \\
\text { et al. } \\
\text { (2011) (73) }\end{array}$ & $\begin{array}{l}\text { Randomised, } \\
\text { parallel, } \\
\text { controlled trial }\end{array}$ & $\begin{array}{l}25 \text { men and } \\
\text { women } \\
\text { (mean age: } \\
\text { blueberry } \\
\text { group } 31 \pm \\
13 \text {; control } \\
33 \pm 16 \text { ) }\end{array}$ & $\begin{array}{l}\mathrm{BMI}<30 \\
\mathrm{~kg} / \mathrm{m}^{2} . \text { No } \\
\text { reported CVD } \\
\text { or other risk } \\
\text { factors. }\end{array}$ & $\begin{array}{l}250 \mathrm{~g} \text { fresh BB daily } \\
\text { then } 375 \mathrm{~g} \text { on the } \\
\text { final day, } 1 \mathrm{~h} \text { prior to } \\
2.5 \mathrm{~h} \text { running }\end{array}$ & N/A & $\begin{array}{c}\text { Normal } \\
\text { dietary habits }\end{array}$ & $\begin{array}{l}\text { Daily } \\
\text { consumpti } \\
\text { on: } 6 \\
\text { weeks }\end{array}$ & $\begin{array}{c}\text { Reduction in plasma F2- } \\
\text { isoprostanes, urinary 5-OHMU and } \\
\text { significant increases in plasma IL-10 } \\
\text { in blueberry group }\end{array}$ \\
\hline $\begin{array}{l}\text { Nair et al. } \\
\text { (2017) (74) }\end{array}$ & $\begin{array}{l}\text { Randomised, } \\
\text { double-blind, } \\
\text { parallel, } \\
\text { controlled trial }\end{array}$ & $\begin{array}{l}27 \text { men and } \\
\text { women } \\
\text { (mean age: } \\
\text { blueberry } \\
\text { group } 55 \pm \\
2, \text { Placebo } \\
\text { group } 59 \pm \\
\text { 3) }\end{array}$ & $\begin{array}{l}\text { Metabolic } \\
\text { syndrome } \\
\text { (defined by } \\
\text { WHO) }\end{array}$ & $\begin{array}{l}22.5 \text { g freeze dried } \\
\text { BB powder + vanilla } \\
\text { flavour, fat-free } \\
\text { vanilla yogurt, skim } \\
\text { milk + water }\end{array}$ & 290.3 & $\begin{array}{l}\text { Fat-free vanilla } \\
\text { yogurt, skim } \\
\text { milk, sugar, } \\
\text { fibre water } \\
\text { and colours }\end{array}$ & $\begin{array}{l}\text { Twice } \\
\text { daily } \\
\text { consumpti } \\
\text { on: } 6 \\
\text { weeks }\end{array}$ & $\begin{array}{l}\text { Blueberry group had lower levels of } \\
\text { ROS and superoxide radical levels, } \\
\text { elevated myeloid dendritic cells and } \\
\text { reduced inflammatory markers } \\
\text { (TNFa, TLR4, IL-6) in monocytes }\end{array}$ \\
\hline $\begin{array}{l}\text { Nyberg et } \\
\text { al. (2013) } \\
\text { (66) }\end{array}$ & $\begin{array}{l}\text { Randomised, } \\
\text { cross-over, } \\
\text { controlled trial }\end{array}$ & $\begin{array}{l}32 \text { men and } \\
\text { women } \\
\text { (mean age: } \\
28 \pm 7 \text { ) }\end{array}$ & $\begin{array}{l}\text { Healthy (free } \\
\text { from major } \\
\text { disease) }\end{array}$ & $\begin{array}{l}150 \mathrm{~g} \text { BB with } \\
\text { exercise }\end{array}$ & $N / A$ & $\begin{array}{l}\text { Exercise } \\
\text { without } \\
\text { blueberries }\end{array}$ & $\begin{array}{l}4 \text { weeks } \\
\text { with } \\
\text { running } \\
\text { then } 4 \\
\text { weeks of } \\
\text { minimal } \\
\text { exercise }\end{array}$ & $\begin{array}{l}\text { Fasting glucose and HDL-cholesterol } \\
\text { increased in the blueberry group. } \\
\text { Triglycerides fell in the control } \\
\text { group }\end{array}$ \\
\hline
\end{tabular}




\begin{tabular}{|c|c|c|c|c|c|c|c|c|}
\hline $\begin{array}{l}\text { One- } \\
\text { Moore et } \\
\text { al. (2016) } \\
\text { (70) }\end{array}$ & $\begin{array}{l}\text { Randomised, } \\
\text { double-blind, } \\
\text { crossover, } \\
\text { controlled trial }\end{array}$ & $\begin{array}{l}23 \text { men and } \\
\text { women } \\
\text { (mean age: } \\
30 \pm 3 \text { ) }\end{array}$ & $\begin{array}{c}\text { Healthy (BMI: } \\
21.9 \pm 0.4 \\
\mathrm{~kg} / \mathrm{m}^{2} \text { ) }\end{array}$ & $\begin{array}{l}24.1 \mathrm{~g} \text { or } 48.2 \mathrm{~g} \mathrm{BB} \\
\text { powder with } \\
\text { moderately high-fat } \\
\text { breakfast }\end{array}$ & $\mathrm{N} / \mathrm{A}$ & $\begin{array}{c}\text { macro- and } \\
\text { micronutrient } \\
\text { matched } \\
\text { placebo } \\
\text { powder + } \\
\text { moderately } \\
\text { high-fat } \\
\text { breakfast }\end{array}$ & $\begin{array}{l}\text { Acute: } \\
\text { samples } \\
\text { at } \\
\text { baseline } \\
\text { and } 3.5 \mathrm{~h} \\
\text { post- } \\
\text { consumpti } \\
\text { on }\end{array}$ & $\begin{array}{l}48.2 \mathrm{~g} \text { blueberry reduced IL- } 6 \\
\text { compared to the placebo. } 24.1 \mathrm{~g} \\
\text { blueberry decreased LPL-induced } \\
\text { secretion of IL-1 } \beta \text { compared with } \\
\text { placebo }\end{array}$ \\
\hline $\begin{array}{l}\text { Riso et al. } \\
\text { (2013) (57) }\end{array}$ & $\begin{array}{l}\text { Randomised, } \\
\text { single-blind, } \\
\text { crossover, } \\
\text { controlled trial }\end{array}$ & $\begin{array}{c}18 \text { males } \\
\text { (mean age: } \\
48 \pm 10 \text { ) }\end{array}$ & $\begin{array}{c}\text { BMI: } 24.8 \pm \\
2.6 \mathrm{~kg} / \mathrm{m}^{2} . \\
\text { With at least } \\
\text { one CVD risk } \\
\text { factor } \\
\text { (American } \\
\text { Heart } \\
\text { Association) }\end{array}$ & $\begin{array}{l}25 \mathrm{~g} \text { freeze-dried } \\
\text { wild BB powder + } \\
250 \mathrm{ml} \text { water }\end{array}$ & 375 & $\begin{array}{l}250 \mathrm{ml} \text { water } \\
\text { + fructose, } \\
\text { glucose, citric } \\
\text { acid, blueberry } \\
\text { flavour and } \\
\text { food colouring }\end{array}$ & $\begin{array}{c}\text { Daily } \\
\text { consumpti } \\
\text { on: } 6 \\
\text { weeks, } \\
\text { Washout } \\
\text { for } \\
\text { crossover: } \\
6 \text { weeks }\end{array}$ & $\begin{array}{l}\text { No change in RHI. Reduction in } \\
\text { levels of oxidised DNA and } \\
\text { increased resistance to oxidatively } \\
\text { induced DNA damage }\end{array}$ \\
\hline $\begin{array}{l}\text { Rodriguez- } \\
\text { Mateos et } \\
\text { al (2019) } \\
\text { (23) }\end{array}$ & $\begin{array}{l}\text { Randomised, } \\
\text { double-blind, } \\
\text { crossover, } \\
\text { controlled trial }\end{array}$ & $\begin{array}{c}5 \text { males } \\
\text { (mean age: } \\
23 \pm 3 \text { ) }\end{array}$ & $\begin{array}{l}\text { Healthy (BMI: } \\
24 \pm 3 \mathrm{~kg} / \mathrm{m}^{2} \text { ) }\end{array}$ & $\begin{array}{l}\text { Freeze-dried BB } \\
\text { powder } 11 \mathrm{~g} \\
\text { (+water) or pure } \\
\text { anthocyanins } \\
(160 \mathrm{mg})\end{array}$ & 150 & $\begin{array}{l}3 \text { control } \\
\text { drinks: a) } \\
\text { fructose, b) } \\
\text { fructose + } \\
\text { fibre, c) } \\
\text { macro- and } \\
\text { micronutrient } \\
\text { matched } \\
\text { control }\end{array}$ & $\begin{array}{l}1,2 \text { and } 6 \\
\text { h post } \\
\text { consumpti } \\
\text { on }\end{array}$ & $\begin{array}{l}\text { Blueberry and anthocyanin } \\
\text { treatments increased FMD by } 2-3 \%\end{array}$ \\
\hline $\begin{array}{l}\text { Rodriguez- } \\
\text { Mateos et } \\
\text { al. (2019) } \\
\quad \text { (23) }\end{array}$ & $\begin{array}{l}\text { Randomised, } \\
\text { double-blind, } \\
\text { parallel } \\
\text { controlled trial }\end{array}$ & $\begin{array}{l}40 \text { males } \\
\text { (mean age: } \\
33 \pm 6 \text { ) }\end{array}$ & $\begin{array}{l}\text { Healthy (BMI: } \\
24 \pm 3 \mathrm{~kg} / \mathrm{m}^{2} \text { ) }\end{array}$ & $\begin{array}{l}\text { Freeze-dried BB } \\
\text { powder } 11 \mathrm{~g} \\
\text { (+water) }\end{array}$ & 150 & $\begin{array}{l}\text { macro- and } \\
\text { micronutrient } \\
\text { matched } \\
\text { control drink } \\
\text { (11 g powder) }\end{array}$ & $\begin{array}{l}\text { Twice } \\
\text { daily } \\
\text { consumpti } \\
\text { on: } 4 \\
\text { weeks and } \\
\text { baseline } \\
\text { vs } 2 \mathrm{~h} \text { at } \\
\text { each visit }\end{array}$ & $\begin{array}{c}\text { Blueberry increased FMD by } 1.5 \% \\
\text { after } 2 \mathrm{~h} \text { and by } 2.3 \% \text { after } 4 \text { weeks } \\
\text { consumption, } 24 \mathrm{~h} \mathrm{SBP} \text { reduced by - } \\
5.6 \mathrm{mmHg}\end{array}$ \\
\hline
\end{tabular}




\begin{tabular}{|c|c|c|c|c|c|c|c|c|}
\hline $\begin{array}{l}\text { Rodriguez- } \\
\text { Mateos et } \\
\text { al. (2014) } \\
\quad(56)\end{array}$ & $\begin{array}{l}\text { Randomised, } \\
\text { double-blind, } \\
\text { crossover, } \\
\text { controlled trial }\end{array}$ & $\begin{array}{l}10 \text { males } \\
\text { (mean age } \\
27 \pm 1 \text { ) }\end{array}$ & $\begin{array}{l}\text { Healthy (BMI } \\
25 \pm 0.8 \text { ) }\end{array}$ & $\begin{array}{l}\text { Blueberry containing } \\
\text { baked product } \\
\text { (containing } 34 \mathrm{~g} \\
\text { freeze-dried BB), or } \\
34 \mathrm{~g} \text { freeze-dried BB }\end{array}$ & $\begin{array}{l}196 \mathrm{mg} \text { in the } \\
\text { baked product } \\
\text { and } 339 \mathrm{mg} \text { in } \\
\text { the } \\
\text { unprocessed } \\
\text { BB powder }\end{array}$ & $\begin{array}{c}\text { Control } \\
\text { matched to } \\
\text { baked product }\end{array}$ & $\begin{array}{l}1,24 \text { and } \\
6 \text { hours } \\
\text { post- } \\
\text { consumpti } \\
\text { on }\end{array}$ & $\begin{array}{l}\text { FMD } \uparrow \text { at } 1,2 \text { and } 6 \mathrm{~h} \text { (maximum } \\
\uparrow \text { at } 2 \mathrm{~h} \text { of } 2.6 \% \text { ) in the blueberry } \\
\text { baked product. The findings were } \\
\text { similar in the BB powder, but the } \\
\text { FMD } \uparrow \text { was maximum at } 1 \mathrm{~h} \text { rather } \\
\text { than } 2 . \mathrm{BP} \text { was not affected. }\end{array}$ \\
\hline $\begin{array}{l}\text { Rodriguez- } \\
\text { Mateos et } \\
\text { al. (2013) } \\
\quad(\mathbf{5 2})\end{array}$ & $\begin{array}{l}\text { Randomised, } \\
\text { double-blind, } \\
\text { crossover, } \\
\text { controlled trial }\end{array}$ & $\begin{array}{l}10 \text { males } \\
\text { (mean age: } \\
27 \pm 1 \text { ). }\end{array}$ & $\begin{array}{l}\text { Healthy (BMI: } \\
25 \pm 0.8 \\
\mathrm{~kg} / \mathrm{m}^{2} \text { ) }\end{array}$ & $\begin{array}{l}\text { Freeze-dried BB } \\
\text { powder } 34,57 \text { and } \\
80 \mathrm{~g} \text { (+ water). }\end{array}$ & $\begin{array}{c}310,517 \text { and } \\
724\end{array}$ & $\begin{array}{l}\text { macro- and } \\
\text { micronutrient } \\
\text { matched } \\
\text { control drink } \\
\text { (to the } 57 \mathrm{~g} \\
\text { dose) }\end{array}$ & $\begin{array}{l}\text { Acute: } 24 \\
\text { hours } \\
\text { (measure } \\
\text { d at } 0,1 \\
2,4,6 \text { and } \\
24 \mathrm{~h} \text { ) }\end{array}$ & $\begin{array}{c}\text { FMD increased after } 34-80 \mathrm{~g} \\
\text { blueberry at } 1-2 \mathrm{~h} \text { and } 6 \mathrm{~h} \text { post- } \\
\text { consumption. Phenolic metabolites } \\
\text { also peaked at } 1-2 \mathrm{~h} \text { and } 6 \mathrm{~h} \text { and } \\
\text { neutrophil NADPH oxidase activity } \\
\text { decreased }\end{array}$ \\
\hline $\begin{array}{l}\text { Rodriguez- } \\
\text { Mateos et } \\
\text { al. (2013) } \\
\quad(\mathbf{5 2})\end{array}$ & $\begin{array}{l}\text { Randomised, } \\
\text { double-blind, } \\
\text { crossover, } \\
\text { controlled trial }\end{array}$ & $\begin{array}{l}11 \text { males } \\
\text { (mean age: } \\
27 \pm 1 \text { ) }\end{array}$ & $\begin{array}{l}\text { Healthy (BMI: } \\
22 \pm 0.9 \\
\mathrm{~kg} / \mathrm{m}^{2} \text { ) }\end{array}$ & $\begin{array}{l}\text { Freeze-dried BB } \\
\text { powder } 14,28,34, \\
57 \text { and } 80 \mathrm{~g} \mathrm{(+} \\
\text { water). }\end{array}$ & $\begin{array}{c}129,258,310 \\
517 \text { and } 724\end{array}$ & $\begin{array}{l}\text { macro- and } \\
\text { micronutrient } \\
\text { matched } \\
\text { control drink } \\
\text { (to the } 57 \mathrm{~g} \mathrm{BB} \\
\text { dose) }\end{array}$ & Acute: $1 \mathrm{~h}$ & $\begin{array}{c}\text { FMD increased (at } 1 \mathrm{~h} \text { ) dose } \\
\text { dependently up to } 34 \mathrm{~g} \text { blueberry } \\
\text { powder then reached a plateau at } \\
\text { higher intakes }\end{array}$ \\
\hline $\begin{array}{l}\text { Stote et al. } \\
\text { (2017) (49) }\end{array}$ & $\begin{array}{l}\text { Randomised, } \\
\text { single-blind, } \\
\text { crossover, } \\
\text { controlled trial }\end{array}$ & $\begin{array}{l}20 \text { women } \\
\text { (mean age: } \\
53 \pm 6 \text { ) }\end{array}$ & $\begin{array}{l}\text { Two risk } \\
\text { factors for } \\
\text { type } 2 \\
\text { diabetes } \\
\text { (Canadian } \\
\text { Diabetes } \\
\text { Association) }\end{array}$ & $240 \mathrm{ml} \mathrm{BB}$ juice & 314 & $\begin{array}{c}240 \mathrm{ml} \\
\text { placebo: } \\
\text { Water, } \\
\text { colouring, } \\
\text { flavours, sugar }\end{array}$ & $\begin{array}{l}\text { Daily } \\
\text { consumpti } \\
\text { on for } 1 \\
\text { week }\end{array}$ & $\begin{array}{c}\text { Nitric oxide levels increased in the } \\
\text { blueberry group compared to } \\
\text { placebo }\end{array}$ \\
\hline $\begin{array}{l}\text { Stull et al. } \\
\text { (2010) (67) }\end{array}$ & $\begin{array}{l}\text { Randomised } \\
\text { double-blind, } \\
\text { parallel, } \\
\text { controlled trial }\end{array}$ & $\begin{array}{l}32 \text { men and } \\
\text { women } \\
\text { (mean age: } \\
\text { blueberry } \\
\text { group } 54 \pm \\
3 \text {; control } 49 \\
\pm 3 \text { ) }\end{array}$ & $\begin{array}{l}\text { Obese }(\mathrm{BMI} \text { : } \\
\left.32-45 \mathrm{~kg} / \mathrm{m}^{2}\right) \\
\text { nondiabetic } \\
\text { insulin- } \\
\text { resistant }\end{array}$ & $\begin{array}{l}22.5 \text { g freeze-dried } \\
\text { BB + light yogurt, } \\
\text { skim milk, vanilla } \\
\text { flavour and Splenda }\end{array}$ & 334 & $\begin{array}{l}\text { Light yogurt, } \\
\text { skim milk, } \\
\text { fibre, sugar, } \\
\text { blueberry } \\
\text { flavour, red } \\
\text { and blue } \\
\text { colour. }\end{array}$ & $\begin{array}{l}\text { Twice } \\
\text { daily } \\
\text { consumpti } \\
\text { on: } 6 \\
\text { weeks }\end{array}$ & $\begin{array}{l}\text { Improved insulin sensitivity } \\
\text { (hyperinsulinemic-euglycemic } \\
\text { clamp) in blueberry group }\end{array}$ \\
\hline
\end{tabular}




\begin{tabular}{|c|c|c|c|c|c|c|c|c|}
\hline $\begin{array}{l}\text { Stull et al. } \\
\text { (2015) (54) }\end{array}$ & $\begin{array}{l}\text { Randomised, } \\
\text { double-blind, } \\
\text { parallel } \\
\text { controlled trial }\end{array}$ & $\begin{array}{c}44 \text { men and } \\
\text { women } \\
\text { (mean age: } \\
\text { blueberry } \\
\text { group } 55 \pm \\
2, \text { Placebo } \\
\text { group } 59 \pm \\
\text { 2) }\end{array}$ & $\begin{array}{c}\text { Metabolic } \\
\text { syndrome } \\
\text { (defined by } \\
\text { WHO) }\end{array}$ & $\begin{array}{l}22.5 \mathrm{~g} \text { freeze dried } \\
\text { BB powder + vanilla } \\
\text { flavour, light yogurt, } \\
\text { skim milk and water }\end{array}$ & 290 & $\begin{array}{l}\text { Fat-free vanilla } \\
\text { yogurt, skim } \\
\text { milk, sugar, } \\
\text { fibre water } \\
\text { and colours }\end{array}$ & $\begin{array}{l}\text { Twice } \\
\text { daily } \\
\text { consumpti } \\
\text { on: } 6 \\
\text { weeks }\end{array}$ & $\begin{array}{c}\text { RHI improved in the blueberry } \\
\text { group after adjusting for body fat \% } \\
\text { and gender }\end{array}$ \\
\hline
\end{tabular}

$B B$; blueberry 